УПК, согласно которому третье лицо имеет права, предусмотренные действующим УПК для подозреваемого, обвиняемого, в части, касающейся ареста имущества. Наделение третьего лица такими правами является неоправданным ввиду следующего. Во-первых, подозреваемый или обвиняемый имеет право отказаться от предоставления каких-либо показаний. Во-вторых, возникают ситуации, при которых лицо, которому известны или могут быть известны обстоятельства, подлежащие установлению при расследовании, то есть свидетель, является также и третьим лицом, но по УПК пользуется правами подозреваемого, обвиняемого. В-третьих, в УПК не урегулирован порядок допроса этого лица.

Ключевые слова: третье лицо, арест имущества, права, наложение ареста, специальная конфискация, процессуальные права, представитель третьего лица.

Smaliuk T. Rights of a Third Party Whose Property is under the Decision of Arrest in Criminal Proceedings. The article interprets the controversial issues concerning the legal status of a third person on whose property the question of arrest is being considered. The author criticizes Article 64-2 of the Criminal Procedural code of Ukraine and indicates to its textual shortcomings, and suggests his own author's editing of Part 2 of Article 64-2 of the Criminal Procedural code of Ukraine. The study argues that not all of the rights of a third party whose property is under the decision of confiscation can be attributed to those rights that directly relate to the seizure of property. Some rights are to be specified. The author concludes that the criminal procedural law should provide an exhaustive list of the rights of a third party, on whose property the question of arrest is being considered by an investigating judge, and further in the pre-trial investigation and litigation. The introduction of amendments to the Criminal Procedural code, proposed by the author, will significantly improve the provisions of criminal procedural legislation on the procedural rights of a third party, on whose property the question of arrest is being considered. We share the opinion expressed in the science of criminal procedure that the provisions of Part 3 of Art. 64-2 of the Criminal Procedural code is legally incomplete. According to a Part 3 of Art. 64-2 of the Criminal Procedural code the third party has the rights provided by the current Criminal Procedural code for the suspect, accused, in the part relating to the seizure of property. Giving such rights to a third party is unjustified in view of the following. Firstly, the suspect or accused has the right to refuse from giving any evidence. Secondly, there are situations in which a person who knows or may know the circumstances to be established during the investigation, the witness, is also a third party, and under the Criminal Procedural code uses the rights of the suspect, accused. Thirdly, the Criminal Procedural code does not regulate the procedure for interrogating this person.

Key words: third party, seizure of property, rights, arrest, special confiscation, procedural rights, third party representative.

УДК 347.96

DOI https://doi.org/10.32782/2409-4544/2019-2/21

Б. Чупринський

\title{
Професійна культура як фактор професійної діяльності юриста
}

У статті досліджено процес формування професійної культури майбутніх юристів. Охарактеризовано види людської діяльності. Визначеноя основні компоненти структури професійної діяльності юриста. Піддано аналізу поняття «комунікативна компетенція юриста», їі значення в професійній діяльності. Професійну діяльність можна визначити як специфічну людську форму цілеспрямованої активності в конкретній трудовій галузі, що обумовлена потребами життєдіяльності в суспільстві, яка спрямована на реалізацію цих потреб, зміст якої складає доцільна його зміна $\mathrm{i}$ перетворення. Юридична діяльність базується на міцних теоретичних юридичних знаннях, практичних навиках, котрі становлять основу професійної діяльності. Зроблено висновок про те, що професійна культура фундаментально впливає на професійну діяльність юриста, пов'язується 3 безперервним процесом його виховання, освіти, обумовлена специфікою його юридичної діяльності. Професійна культура тісно пов'язана $з$ культурою особистості, яку характеризує, перш за все, праця, діяльність, виконання службових обов'язків і особливо їх характер, оскільки тільки працею, власними

(C) Чупринський Б., 2019 
якостями людина перетворює світ і реалізує свої сили і здібності. Успішна професійна діяльність юристів вимагає наявності у них певних умінь, які формуються під впливом навчання, праці, інших обставин життя. Система підготовки майбутніх юристів у вищих навчальних закладах має бути спрямована на теоретико-практичні аспекти майбутньої професійної діяльності, що буде запорукою якісного виконання ними службових обов'язків.

Ключові слова: діяльність; навчальна діяльність; професійна діяльність; юридична діяльність; професійна культура; професійна компетенція; комунікативна компетенція; комунікативні вміння.

Постановка наукової проблеми та її значення. Правова культура - одна із частин загальної культури народу, базується на іiі початках, є реальним показником рівня іiі розвитку, менталітету народу. Формування правової культури це історичний процес тісно взаємопов'язаний з розвитком інших видів культур - політичною, моральною, естетичною. Формування високої правової культури це комплексна проблема. Їх об'єднує спільність завдання - створення морально-правового клімату в суспільстві, який гарантує реальну свободу поведінки особи і з'єднанні з відповідальністю перед суспільством, забезпечує іiї права, соціальну захищеність, пошану іiї гідності, тобто ставить людину в центр економічних, соціальних, політичних, культурних процесів. Правова культура $є$ фундаментом професійної культури юриста.

Формування професійної культури юриста відбувається поетапно i пов'язується 3 неперервним процесом його виховання, освіти, та специфікою його юридичної діяльності. Існуюча досі система підготовки у вузах великою мірою спрямована на теоретичне осмислення переважно компонентів професійної діяльності (передметів навчального циклу), а не на професію загалом з їі варіативними, неповторними нюансами.Процес формування особистості професіонала і період навчання у вузах обумовлюється, з одного боку, синтезом здібностей, активності та спрямованості особистості, з іншого - вимогами діяльності, що детерміновані особливостями ії змісту, засобами та умовами організації. Таким чином, проблема формування професійної культури майбутніх юристів вимагає розгляду низки супутніх понять, як-от: діяльність, види професійної діяльності, готовність студентів до професійної діяльності.

Аналіз досліджень цієї проблеми. Проблема діяльності була предметом дослідження багатьох учених, зокрема, Л. І. Анцифірова, А. Г. Бала., М. В. Деміна, М. С. Кагана, О. М. Леонтьєва, С. Л. Рубінштейна, С. С. Сливки та ін.

Навчальна діяльність у вищій школі на психологічному і педагогічному рівнях розглядалася

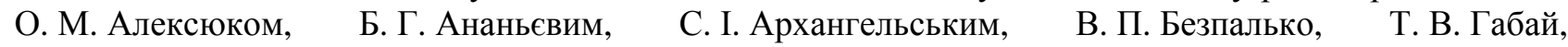
М. І. Дьяченко, В. І. Загвязинським, І. І. Ільясовим, Л. А. Кандибович та ін., як специфічна діяльність, головною особливістю якої $є$ професійна направленість, тобто, набуття досвіду вирішення навчальнопізнавальних завдань, пов'язаних з формуванням професійної майстерності.

Формулювання мети та завдань статті. Метою статті вважаємо розкриття процесу формування, змісту та проявів професійної культури юристів.

Відтак, завданнями цього ослідження є наступне: 1) дослідити професійну культуру, іiі фундаментальний вплив на успішну професійну діяльність юристів; 2) вказати на важливість системи підготовки майбутніх юристів у вузах, яка вимагає наявності в них певних умінь, які формуються під впливом навчання, праці, інших обставин життя.

Виклад основного матеріалу й обгрунтування отриманих результатів дослідження. Професійна культура тісно пов'язана із культурою особи, яку характеризує, перш за все, праця, діяльність, виконання службових обов'язків і особливо їх ступінь, оскільки тільки працею, іії якістю людина перетворює світ і опредмечує свої сили та здібності. Крім того, культура особи - це філософська категорія, що відображає рівень соціалізації людини, ії придатність для того чи іншого виду професійної діяльності.

Юридична діяльність базується на міцних теоретичних юридичних знаннях, практичних навиках, котрі становлять основу професійної діяльності. Так, М. С. Каган під діяльністю розуміє «спосіб існування людини, а людину розглядає як «діяльну істоту». До структури діяльності автор відносить такі іiі складові: матеріально-практичні, інтелектуальні, духовні операції; зовнішні і внутрішні процеси; «діяльністю є робота думки такою ж мірою, як і діяльність руки, процес пізнання такою ж мірою, як людська поведінка» [4, с. 55].

О. М. Леонтьєв розглядає діяльність як «систему, що входить до системи відношень суспільства, поза цими відношеннями людська діяльність зовсім не існує» [8, с. 82]. Діяльність кожної людини, зауважує автор, залежить від іiі місця в суспільстві, від умов, що випадають на іiі 
долю, від того, як вона складується в неповторних індивідуальних обставинах. Основною характеристикою діяльності є їі предметність. Залежно від предмета діяльності розрізнюють і різні види діяльності, їі спрямованість.

Отже, діяльність - найвищою мірою динамічна система, у ній постійно відбуваються трансформації: акт діяльності втрачає мотив і перетворюється на дію, що реалізує інше ставлення до світу, іншу діяльність; навпаки, дія може набути самостійної спонукальної сили і стати актом діяльності; дія може трансформуватися в операцію, почати реалізувати певні цілі. Різні діяльності можна класифікувати за різними ознаками. Головною з них є якісна своєрідність діяльності, за цією ознакою можна виділити трудову, ігрову, пізнавальну діяльності (і дії) як види діяльності. Іншим критерієм є зовнішній, матеріальний, або ж внутрішній, теоретичний характер діяльності або дії - це різні форми діяльності. Зовнішні і внутрішні форми діяльності взаємозалежні і переходять одна в одну в процесах інтеріоризації і екстеріоризації. При цьому дія одного виду або типу може входити як утворюючий елемент у діяльність іншого типу або виду: теоретична дія може входити до складу практичної, наприклад трудової діяльності, трудова дія - до складу ігрової діяльності і т. ін. [10].

Навчання виступає як вид діяльності, метою якого $є$ набуття людиною знань, умінь та навичок. Метою та предметом навчальної діяльності є саме певні знання та вміння [2, с. 132].

Б. М. Теплов вважає, що у процесі навчання загальні знання, уміння та здібності набувають іншого соціо-особистісного статусу - вони, будучи вихідною базою, переростають у професійну майстерність [12, с. 20]. Таким чином, діяльність людини лежить у самій основі існування суспільства та його розвитку, формування його цінностей. Вона є джерелом життя людини, а також розвитку та формування іiі як особистості. Основними видами діяльності, які притаманні людині і відповідають загальним потребам, а точніше - видам соціальної людської активності, є спілкування, гра, навчання i праця. Усім цим видам діяльності властивий розвиваючий характер [4, с. 131].

У розмаїтті людських діяльностей особливе місце посідає професійна діяльність. Дефініція «професія» визначається як рід занять, трудової діяльності, що вимагає певних знань і навичок та $є$ для когось джерелом існування; фах, спеціальність, ремесло, кваліфікація [5, с. 326], вона «потребує певної підготовки і є зазвичай джерелом існування, відображає стійкий розподіл праці за основними напрямками виробництва, службової діяльності» [2, с. 48].

Професійну діяльність, на наш погляд, можна визначити як специфічну людську форму цілеспрямованої активності в конкретній трудовій галузі, що обумовлена потребами життєдіяльності в суспільстві, яка спрямована на реалізацію цих потреб, зміст якої складає доцільна його зміна i перетворення.

Всі види людської діяльності, незважаючи на їх відмінності, мають одну будову. Між окремими видами діяльності існують чітко визначені залежності, знаючи які, можна за одними елементами діяльності будувати інші [12]. Така робота передбачає розвиток передусім базисного обсягу загальних інваріантних дій та операцій, які, у свою чергу, сприяють ефективнішому відпрацюванню навчальних здібностей.

Будь-яка професійна діяльність складається із взаємодії людини-фахівця як суб'єкта цієї діяльності з предметом (об'єктом) праці за допомогою знаряддя, що є найбільш рухливою, активною структурною частиною цієї діяльності, і піддається змінам. Професійна обумовленість багаторазової (повторюваної) взаємодії суб'єкта і об'єкта праці дає можливість виявити закономірні професійні дії, яким відповідають однакові сукупності психічних процесів, станів, умінь і навичок, якостей особистості.

Б. Г. Ананьєв, Л. І. Божович, О. В. Запорожець, О. М. Леонтьєв, О. О. Смирнов та ін. у своїх працях визначили основні компоненти психологічної структури професійної діяльності, як-от: мета діяльності; умови, за яких протікає діяльність; особливості і специфіка предмета (об'єкта) і знарядь взаємодії; шляхи і засоби досягнення мети діяльності.

На думку Е. Е. Карпової, саме професія, об'єднує, інтегрує масу людей, визначаючи їхню подібність у поглядах, оцінках, нормах поведінки і діяльності, поглинаючи індивідуальне буття соціальним способом існування. Будучи включеною в систему суспільного виробництва і відповідних їй суспільних відносин, професія утворює в них самостійну структуру, що стає об'єктом цілеспрямованого регулювання з боку суспільства і його державних структур [5, с. 161].

Є. А. Клімов запропонував авторський метод класифікації різних видів професій за предметом і метою праці, за характером дій, знаряддями праці та іiі умовами [6]. Так, за предметом праці всі професії автор поділяє на біономічні (природа), техномічні (техніка), сигномічні (знаки), артономічні (художні образи) і соціономічні, за О. М. Леонтьєвим, (взаємодія людей). Відповідно до цього, Є. А. Клімов визначив п’ять схем професійної діяльності «Людина - Природа», «Людина - Техніка», 
«Людина - Знак», «Людина - Образ», «Людина - Людина».

Професія юриста, за Є. А. Клімовим, належать до професій «Людина - Людина». На його думку, цей тип професії визначається такими якостями: стійким хорошим самопочуттям у ході роботи $з$ людьми, потребою у спілкуванні: здібністю подумки ставити себе на місце іншої людини, здібністю швидко розуміти наміри, настрій, думки інших людей, здібністю швидко орієнтуватися у взаємовідносинах людей, здібністю добре розуміти, тримати подумки знання щодо особистісних якостей багатьох і різних людей і т. п. [6, с. 175]. За Є. А. Клімовим, людині цієї професійної схеми притаманне: вміння керувати, вчити, виховувати, «здійснювати корисні дії обслуговування різних потреб людей»; вміння слухати і вислуховувати; широкий кругозір; «душезнавська спрямованість розуму, спостережливість до прояву почуттів, розуму і характеру людини, до ії поведінки, вміння чи здібність подумки уявляти, моделювати саме ії внутрішній світ, а не приписувати їй свій власний чи якийсь інший, знайомий їй з досвіду»; «проектувальний підхід до людини, що заснований на впевненості - «людина завжди може стати кращою»; здібність співпереживання; спостережливість; «глибока і оптимістична переконливість щодо правильності ідей служіння народу загалом; вирішення нестандартних ситуацій; високий ступінь саморегуляції» [6, с. 147].

Водночас Є. А. Клімов дає перелік протипоказань до цього типу професій. 3-поміж них: дефекти і невиразність мовлення, «замкненість, зануреність у себе, некомунікабельність, яскраво виражені фізичні недоліки, неспритність, зайва повільність, байдужість до людей, відсутність ознак безкорисного інтересу до людини - інтересу «просто так» [6, с. 36-40]. На нашу думку, всі професійні протипоказники прямо стосуються всіх видів юридичних, правоохоронних професій.

Ці вимоги суспільної практики та професійної діяльності знаходить своє відображення в Конституції України, постановах Верховної Ради України, рішеннях Міністерства внутрішніх справ. Сферу юридичної діяльності, як вважають М. І. Мельник та М. І. Хавронюк [9] характеризують такі властивості:

По-перше, вся юридична діяльність, відбувається лише відповідно до норм чинного законодавства, тільки у встановленому ним порядку і 3 дотриманням цілої низки спеціальних процедур. По-друге, юридична діяльність є завжди владною діяльністю, тобто такою, яка здійснюється за допомогою правового впливу і має загальнообов'язковий характер [9, с. 22]. Тобто, юридична діяльність: це вид трудової діяльності в соціокультурній сфері, що обумовлена потребами правового захисту життєдіяльності людини в конкретному мікро- чи макросередовищі.

Сутність і специфіку юридичних спеціальностей досліджувала низка вчених (В. Г. Андросюк, О. М. Бандурка, В. Л. Васильєв, В. Р. Волков, В. О. Коновалова, Н. М. Конопенко, А. Р. Ратинов та ін.). Загальну характеристику юридичної діяльності дає В. Л. Васильєв [1]. Автор відзначає, що ця діяльність насамперед пов'язана з нормами права, а окремі ії види містять означене поняття вже у самій іiї назві: правозастосувальна, правоохоронна, правозахисна тощо.

Усі юридичні професії харкктерезуються надзвичайним розмаїттям професійних задач, в основі яких лежать правові норми. Діяльність кожної юридичної спеціальності в тій чи іншій мірі містить такі сторони: організаційну, соціальну, пошукову, реконструктивну, комунікативну, посвідчувальну.

Юридична діяльність цілковито підпорядковується правовому регулюванню, саме це, на думку В. Л. Васильєва, накладає відбиток на особистість кожного юриста. Юрист уже на етапі планування своєї діяльності подумки зіставляє свої майбутні професійні дії з нормами законодавства, що регламентують ці дії. Провідною стороною всіх юридичних діяльностей, за В. Л. Васильєвим, $\epsilon$ комунікативна діяльність, що протікає в умовах правового регулювання, що надає особливого відтінку спілкування юриста.

Для більшості юридичних професій характерні: висока емоційна напруженість, що пов’язана здебільшого з негативними емоціями, з необхідністю їх приховувати, а емоційну розрядку відкладати на більш тривалий період часу; здійснення особливих владних повноважень, що надають право і обов' язок застосовувати владу від імені закону, призводить до формування професійно підвищеного почуття відповідальності за наслідок своїх дій; наявність організаційних здібностей - організація власної роботи впродовж дня, тижня, в умовах ненормованого робочого дня. Організація спільної роботи 3 іншими посадовими особами, правоохоронними органами та іншими сторонами в кримінальному процесі; переборення опору з боку окремих осіб, мікрогруп; творчий процес праці [1, c. 201-202].

В. Л. Васильєв розробив професіограму юриста в якій виділено два поняття, які є близькими, але не збігаються за змістом, - компетенція і компетентність. Ці поняття мають безпосереднє відношення до професійної підготовки. Професійна компетенція (від лат. competentia - належність по 
праву) - коло питань, вирішення яких входить в обов'язки фахівця. За «Словником української мови», «компетентний» - який має достатні знання в якій-небудь галузі; який з чого-небудь добре обізнаний; тямущий $[11$, с. 250]. Професійна компетентність відбиває рівень володіння необхідними знаннями та вміннями. У «Словнику іншомовних слів» компетентність - 1) володіння компетенцією, 2) володіння знаннями, які дозволяють судити про щось, а компетенція, у свою чергу, - коло питань, повноважень, в яких дана особа володіє пізнаннями, досвідом. Дослідниця «мінімальної компетенції» В. де Ландшеєр визначає компетентність у широкому розумінні як «поглиблене знання або засвоєне вміння» [7, с. 30].

Комунікативну компетенцію вчені визначають як конгломерат знань, мовних і немовних умінь та навичок спілкування, що людина набуває в ході природної соціалізації, навчання i виховання. «Без сумніву, важливу роль при цьому відіграють природні дані і потенціал індивіда» [3, c. 26]. Водночас Є. С. Кузьмін і Ю. М. Смельянов зауважують, що «гени людини слугують лише модуляторами, а інформацію її мозок бере не з генів, а з оточуючої їі культури» [7, с. 8]. За словами Н. В. Кузьміної, комунікативна компетенція передбачає «здібність до продуктивного спілкування в обмежених і продиктованих умовах», що накладаються службовим обов’язком [3, с. 89]. Відтак, одним із головних критеріїв оцінки продуктивності комунікативної компетенції, за Н. В. Кузьміною, є здібність фахівця таким чином будувати свої взаємовідносини в ході спілкування із співрозмовником, щоб викликати в нього довіру до себе. Ф. К. Думко стверджує, комунікативна компетенція юриста це насамперед вміння спілкуватися з різними верствами населення. Саме у спілкуванні реалізуються соціальні, соціально-психологічні і соціально-педагогічні залежності людей i їхні різноманітні суспільні та міжособистісні відносини. Це вміння вступати в контакт з людьми, будувати спілкування 3 урахуванням вікових і індивідуально психологічних властивостей кожної особистості та окремих груп громадян; своєчасне і адекватне визначення емоційно-психічного стану співрозмовника, його інтересів і нахилів; контроль за плином спілкування [2, с. 93].

Висновки. Професійна культура фундаментально впливає на професійну діяльність юриста, пов'язується 3 неперервним процесом його виховання, освіти, обумовлена специфікою його юридичної діяльності. Професійна культура тісно пов'язана із культурою особи, яку характеризує, перш за все, праця, діяльність, виконання службових обов'язків і особливо їх ступінь, оскільки тільки працею, iї якістю людина перетворює світ і опредмечує свої сили та здібності.

Юридична діяльність базується на міцних теоретичних юридичних знаннях, практичних навиках, котрі становлять основу професійної діяльності.

Отже, успішна професійна діяльність юристів вимагає наявності в них певних умінь, які формуються під впливом навчання, праці, інших обставин життя. Тобто, система підготовки майбутніх юристів у вузах повинна бути спрямована на теоретико-практичні аспекти майбутньої професійної діяльності, що буде запорукою якісного виконання ними службових обов’ язків.

\section{Досерела та література}

1. Васильев В. Л. Юридическая психология / В. Л. Васильев. - СПб. - М., 1998. - 650 с.

2. Думко Ф. К. Підготовка курсантів до професійно-педагогічної роботи з неблагополучними сім'ями. Дис... канд. пед. наук: 13.00.04 / Ф. К. Думко. - Одеса, 2000. - 212 с.

3. Емельянов Ю. Н., К Кузьмин Е. С., Теоретические и методологические основы социальнопсихологического тренинга / Ю. Н. Емельянов, Е. С. Кузьмин. - Л., 1985. - 111 с.

4. Каган М. С. Человеческая деятельность (опыт системного анализа) / М. С. Каган. - М.: Наука, 1974. $-328 \mathrm{c}$.

5. Карпова Е. Е. Сутність професійно-педагогічної діяльності / Е. Е. Карпова // Вісник Одеського інституту внутрішніх справ. - 2011. - №2. - С. 159-165.

6. Климов Е. А. Как выбрать профессию / Е. А. Климов. - М., 2010. - 150 с.

7. Ландшеер В. Концепция «минимальной компетентности» / В. Ландшеер // Перспективы: вопросы образования. - 1988. - №1. - С. 27-34.

8. Леонтьев А. Н. Деятельность. Сознание. Личность / А. Н. Леонтьев. - М., 2008. - 304 с.

9. Мельник М. І., Хавронюк М. І. Суд та інші правохоронні органи. Правоохоронна діяльність. Закони і коментарі / М. І.Мельник, М. І. Хавронюк. - К., 2000. - 435с.

10. Немов Р.С. Психология. В трех книгах. Кн.1. Общие основы психологии. 2-ое издание / Р. С. Немов. - М.: Просвещение: ВЛАДОС, 1995. - 576 с.

11. Новий тлумачний словник української мови: У 4-х т. - Т. 3. - К.: Аконіт, 1999. - 927 с.

12. Теплов Б. М. Избранные труды: в 2-х томах. -Т.1 / Б. М. Теплов. - М.: Педагогика, $1985 .-329$ с. 
Чупринский Б. Профессиональная культура как фактор профессиональной деятельности юриста. В статье исследуется процесс формирования профессиональной культуры будущих юристов. Характеризуется виды человеческой деятельности. Определяются основные компоненты структуры профессиональной деятельности юриста. Анализируется понятие «коммуникативная компетенция юриста», и ее значение в профессиональной деятельности. Профессиональную деятельность можно определить как специфическую человеческую форму целенаправленной активности в конкретной трудовой отрасли, обусловленную потребностями жизнедеятельности в обществе, которая направлена на реализацию этих целей, содержание которой составляет целесообразное его изменение и преобразование. Юридическая деятельность базируется на прочных теоретических юридических знаниях, практических навыках, которые составляют основу профессиональной деятельности. Сделан вывод о том, что профессиональная культура фундаментально влияет на профессиональную деятельность юриста, связывается с непрерывным процессом его воспитания, образования, обусловлена спецификой его юридической деятельности. Профессиональная культура тесно связана с культурой личности, которую характеризует, прежде всего, труд, деятельность, выполнение служебных обязанностей и особенно их характер, поскольку только трудом, его качеством человек преобразует мир и реализует свои силы и способности. Успешная профессиональная деятельность юристов требует наличия у них определенных умений, которые формируются под влиянием обучения, труда, других обстоятельств жизни. Система подготовки будущих юристов в вузах должна быть направлена на теоретико-практические аспекты будущей профессиональной деятельности, что будет залогом качественного выполнения ими служебных обязанностей.

Ключевые слова: деятельность; учебная деятельность; профессиональная деятельность; юридическая деятельность; профессиональная культура; профессиональная компетенция; коммуникативная компетенция; коммуникативные умения.

Chuprynsky B. Professional Ethics as an Integral Part of the Professional Activity of a Lawyer. The article examines the process of formation of the professional culture of future lawyers and characterizes various types of human activity. The author focuses on the main aspects of the professional activity of the lawyer and provides a comprehensive analysis of the notion «communicative competence of a lawyer», paying attention to the importance of this skill in his professional activity. Professional activity, in our opinion, can be defined as a specific human form of purposeful activity in a particular field of work, which is defined by the needs of life in society. Professional activity aims to implement these needs. Legal activity is based on strong theoretical legal knowledge, practical skills, which are the basis of professional activity. The key findings of the study argue that professional culture fundamentally influences the professional activity of a lawyer and is associated with the continuous learning process and professional skills development, arising from the specificity of the legal profession. Professional culture is closely connected with the culture of the person, which is characterized primarily by work, activity, performance of duties, and especially their quality because only by high-quality work a person transforms the world and realizes his/her talents, skills, and abilities. Successful lawyer's professional activity requires durable competencies and skills, which are formed under the influence of education, work, and other life activities. Therefore, the system of the future lawyers training in higher education institutions should focus on the theoretical and practical aspects of the future professional activity, which will be a guarantee of high-quality, effective performance of the duties.

Key words: activity, learning activities, professional activity, legal activity, professional culture, professional competence, communicative competence, communication skills. 